\title{
Justification and Opposition of Mass Killing: Black Sun-The Nanking Massacre
}

\author{
Lung-Lung $\mathrm{Hu}^{1}{ }^{\circledR}$
}

Accepted: 6 October 2020 / Published online: 19 October 2020

(c) The Author(s) 2020

\begin{abstract}
Japan was supposed to obey the law during the second world war. However, the Nanjing Massacre still happened. Hirohito, the Japanese emperor, deliberately avoided mentioning the International Treaties in the imperial rescript of the Great East Asia War in 1937. The Nanking Massacre was carried out according to the Japanese army's interpretation of the imperial rescript. Such a legal interpretation was rooted in the idea that Japan had to educate the Chinese and transform China by killing its people in order to pursue a Greater East Asia Co-Prosperity Sphere led by Japan. In the film Black Sun: The Nanking Massacre (1995), we can see both a justification of and an opposition to killing. In this paper I am going to show how the imperial rescript is used to justify this mass killing is and how opposing arguments are used to show its cruelty and absurdity, which is taken as a means to achieve a greater good.
\end{abstract}

Keywords Nanking massacre - Black sun · The imperial rescript · Lucifer effect · Dishonesty of honest people

\section{Introduction}

Did the Nanking Massacre really happen in 1937? Chinese people, with a plethora of concrete evidence, believe that such tragedy did happen, and many crimes have been trialled, sentenced, and many criminals have been punished, as shown in some researches, such as Documents of Nanking Massacre 南京大屠殺檔案, which was published in 2014 and accepted by Memory of the World in 2015 [1], and Research Japanese War Crimes Records-Introductory Essays (2006). [2] Aside from other atrocities during the second Sino-Japan war, such as raping, plundering, and human experimentation at Unit 731, at least 30,000 Chinese civilians were brutally

Lung-Lung $\mathrm{Hu}$

1lh@du.se

1 Chinese Department, School of Humanities and Media Studies, Dalarna University,

Högskolegatan 2, 79188 Falun, Sweden 
murdered in the Nanking Massacre. However, some extreme right-wing Japanese nationalists are convinced that the Nanking Massacre was fictitious which was a hideous conspiracy trying to make Japan an international enemy. Such as Naoki Hyakuta, a governor of Japan's public broadcaster, NHK, said in a speech on February 3rd 2014 that "In 1938, Chiang Kai-shek tried to publicize Japan's responsibility for the Nanking Massacre, but the nations of the world ignored him. Why? Because it never happened". [3] $]^{1}$ Some other Japanese may admit that some incident really happened in Nanking; however, it was not a massacre but an unavoidable casualty, such as Tanaka Masaki's book What Really Happened in Nanking-The Refutation of a Common Myth [4]. I do not intend to verify the authenticity or the scale of the Nanking Massacre in this paper. My purpose is to illustrate two conflicting discourses, the justification of and opposition to the mass killing as represented in the film Black Sun-The Nanking Massacre, sometimes called Black Sun IV (1995), ${ }^{2}$ directed by Mou Tunfei 牟敦蒂.

There have been other films made about the Nanking Massacre, such as Zhang Yimou's 張藝謀The Flowers of War 金陵十三釵 (2011) and Lu Chuan's 陸川 City of Life and Death 南京! 南京! (2009), but Black Sun-The Nanking Massacre is the most controversial because of its cult character and graphic violent scenes. However, the reason I chose this film is not only because Black Sun IV bluntly shows Japanese soldiers' brutality, but also because it discusses, maybe not intentionally, the reasons for such inhumanity.

In this paper, first, I will explain why the Nanking Massacre occurred from a legal point of view. In history, Hirohito, the Japanese emperor at the time, deliberately avoided mentioning Japan's commitment to International humanitarian law Treaties in the imperial rescript in 1941 in order to justify the Great East Asia War. In the film, the imperial rescript, which is used as a cinematic design that did not exist in 1937 in reality, indirectly offers the Japanese army a legal ground, or an excuse, to ignore the legally binding international agreements which the Japanese government has signed and which regulates states' conduct in war.

The purpose of the imperial rescript in the film is to exempt Japanese soldiers, as well as the government and the emperor himself, from the legal consequences of such an atrocity. However, the cruelty and severity of this mass killing cannot be easily sanctioned, even if the Japanese soldiers are seen as fallible human beings. As my second point, using the theories of Philip Zimbardo and Dan Ariely, I will explain how it is possible for Japanese soldiers to break, through a mass murder, the moral and psychological barrier and cause a mass murder.

\footnotetext{
${ }^{1}$ The original text: 1938 年に蔣介石が日本が南京大虐殺をしたとやたら宣伝したが、世界の国は無視し た。なぜか。そんなことはなかったからです。Please see The Huffington Post https://www.huffingtonpost. jp/2014/02/05/hyakuta-naoki-nanjing_n_4734704.html. The link of the original source “朝日新聞デジタ ル「NHK経営委員の百田氏が応援演説—都知事選」より 2014/02/04 05:56” has been removed.

2 There are three movies about unethical human experimentation conducted by Japanese before Black Sun: the Nanking Massacre was released: 1) Men Behind the Sun 黑太陽731 (1988), 2) Laboratory of the Devil 黑太陽731續集 - 殺人工廠 (1992), 3) A Narrow Escape 黑太陽731完結篇 - 死亡列車 (1994).
} 
Not only does the film explain why Japanese soldiers could cross the last line of human decency to cause such a catastrophe, it also challenges the justification and rationalization of mass killing by using three fictional narratives: (1) a meeting of high ranking officers that takes place after the Nanking massacre and an informal conversation between some of them after this meeting, (2) a monologue by the Commander General Matsui Iwane, and (3) a discussion about swords between the samurai Takayama and Nakajima Kesago. I will analyse these three narratives to show the absurdity of the, legal, moral, and psychological reasons for mass killing and other inhumane acts in war in the film. In the next section, I will first demonstrate the laws, which also are the laws as a historical and legal fact shown in the film, that regulate the acts of Japanese soldiers in war. Even though Japanese soldiers carried out many atrocities during the second Sino-Japanese War, such as devastating the property of non-combatants and conducting biological experiments, I will only focus on the laws regarding mass killing and inhumane treatment of civilians and Chinese soldiers during the Nanking Massacre.

\section{International Law}

The second Sino-Japanese War between China and Japan started in 1937 and the Nanking Massacre, when Japanese troops allegedly killed over 30,000 Chinese civilians, took place between December 1937 and January 1938. Since this was a war when the armies of both parties should have followed the international humanitarian treaties, such as the 1907 Hague Convention which established the legal framework for the 'humane treatment' of prisoners of war (POWs) [5]. The Nanking Massacre should never have happened because the regulations protect civilians and soldiers who have already surrendered. ${ }^{3}$ However, the Japanese army did not follow this Code. The Japanese government had not ratified the Geneva Convention of 1929, which stated, in the reply to the International Committee of the Red Cross (ICRC) after the attacks on Pearl Harbour and Southeast Asia in 1941, that it was:

not in fact bound by the said Convention. Nevertheless, as far as is possible, it intends to apply the Convention, mutatis mutandis, to all prisoners falling into its hands, while at the same time respecting the customs of each nation and people in relation to the food and clothing of prisoners. [7, 521]

This reply shows that the Japanese government's attitude was that its army did not need to sign the convention because any prisoners of war were likely to be treated humanely anyway. However, the prisoners of war were not guaranteed to be treated according to the signed convention, since the 1929 Geneva Convention was not

\footnotetext{
3 According to Article I of the Kellogg-Briand Pact (1928) signed by the Japanese government "The High Contracting Parties solemnly declare in the names of their respective peoples that they condemn recourse to war for the solution of international controversies, and renounce it, as an instrument of national policy in their relations with one another." War cannot be used as a solution for international controversies and the second Sino-Japanese War was not supposed to happen in the first place. [6].
} 
ratified by the Japanese government. That said, as an involved party in the second Sino-Japanese War, the Japanese government had signed up to other international treaties regarding humane treatment in war. Both the 1899 and the 1907 Hague Conventions included clauses covering the treatment of prisoners of war. For example:

Hague II Art. 4. Prisoners of war are in the power of the hostile Government, but not in that of the individuals or corps who captured them. They must be humanely treated. All their personal belongings, except arms, horses, and military papers remain their property. [8]

Hague IV Art. 4. Prisoners of war are in the power of the hostile Government, but not of the individuals or corps who capture them. They must be humanely treated. [9]

Other parts of the Hague Convention had similar humane injunctions, such as:

Hague IV Art. 23. In addition to the prohibitions provided by special Conventions, it is especially forbidden

a. To employ poison or poisoned weapons;

b. To kill or wound treacherously individuals belonging to the hostile nation or army;

c. To kill or wound an enemy who, having laid down his arms, or having no longer means of defence, has surrendered at discretion.... [9]

Since the treatment of prisoners of war has clearly stated that prisoners are not in the hand of those who capture them but still belong to their home country, prisoners cannot be wounded or killed at will and should be humanely treated by the individuals or corps who captured them. Japanese soldiers were supposed to follow the treaty during the second Sino-Japan war, because the Japanese government has signed and ratified the treaty.

Even if existing legal agreements could theoretically be overridden or annulled by a new unratified or unsigned agreement-the 1929 Geneva Convention, Japanese soldiers would have behaved properly if Emperor Hirohito, who to the Japanese was a god, ${ }^{4}$ and whose words presumptively have the same effect in the film, had restrained their conduct.

However, in the film, Emperor Hirohito does not mention humane treatment to Chinese people in his imperial rescript, or, as is fairer, his rescript is not intended to declare war on the Republic of China. ${ }^{5}$ As mentioned before, the imperial rescript

\footnotetext{
${ }^{4}$ George Godwin once said that: "the Japanese people are the race of races, the Herrenvolk of Herrenvolk; that they are of divine origin, and that their Emperor is god made manifest as man. The whole life of Japan centres about this anthropomorphic dogma, and it is probably true to say that Japan is the most united, the most homogeneous, nation on earth under the surface differences of her domestic political life." $[10,11]$.

5 The Emperor's rescript about the declaration of war was announced on December 8th, 1941. This declaration of war (米國及英國二對ス儿宣戰詔書) was on the United States and Great Britain, not to the Republic of China.
} 
in reality did not even exist in 1937, although Black Sun IV mentions it during a conference scene involving Japanese military leaders. Led by General Matsui Iwane, this conference is held after the fall of Nanking to discuss Japanese soldiers' misconduct, which the high ranking officers present all agree had taken. Iwane argues that "Although killing is unavoidable in warfare, we still must observe international law." Other officers refute this claim, saying:

Tani Hisao: From the Emperor's directive, ${ }^{6}$ no mention was made of International law this time.

Matsui Iwane: It's unnecessary to point that out.

Tani Hisao: In the Emperor's Directives for the Japanese-Russian and Ching Dynasty wars.... They all mentioned observing International law. But in this conflict, its absence is not accidental.

Nakajima Kesago: Calling it a conflict rather than a war already makes it different. There are complex reasons behind this. [12]

Calling it a “conflict”, or an “incident”, (shibian 事變or gange干戈7) implies that it is not a war (zhanzheng 戰爭) and that it need not be regulated by the international laws regarding war. Even if this conflict is by definition a war, Japanese soldiers do not need to obey international law because the Emperor's words, which are superior to anything, do not mention the need to do so, like the declarations for the JapaneseRussian and Japanese-Qing Dynasty wars did. However, in the second Sino-Japanese war, Japanese soldiers were still subordinate, so do the soldiers in the film, to the Japanese Army Criminal Codes (明治 Meiji 14年, 1908一明治41年, 1947). In the next section, I will explain these codes and why, because of the interpretation of the Emperor's rescript shown in the movie, they failed to regulate Japanese soldiers' behaviour.

\section{Criminal Codes and Senjinkun 鬥車訓}

Even if there was no Imperial rescript asking Japanese soldiers to follow international law, Japanese soldiers should still have obeyed the Japanese Army Criminal Codes, which are also the same laws that Japanese soldiers in the film should obey, especially chapter 9 , Article $86-88$, that specifically prohibits some acts, such as plundering and raping, ${ }^{8}$ as mentioned in Chapter 9, Article 86-88.

\footnotetext{
${ }^{6}$ The direct English translation in the film is 'directive', however, it is the Imperial Rescript天皇詔書.

7 宣戰大詔謹解, which is the annotation of the Emperor's rescript, uses the term “日支事變”, JapanChina Incident. Compared with “invasion" 侵略 the term China uses, these terms lessen Japan's responsibility and holds China also responsible.

${ }^{8}$ Soldiers who committed rape were usually punished according to the general criminal code as Japanese civilians. According to the law, the victim was responsible to press charges on the crime of rape. Since rape victims are mostly murdered, it will be impossible for them to press charges against their assailants. As a result, the criminal code against rape was not able to stop rape from happening, and the actual numbers of rape cases must be higher than reported rape cases during the second Sino-Japan War. See Sexual Violence of the Army 軍による性暴力. [13].
} 
Article 86: The empire soldiers, who plunder the inhabitants' properties on the battlefield or on the land occupied by the imperial army, will be sentenced to an imprisonment of more than a year. If a soldier, who is guilty of the previous crime, rapes a woman, he will be sentenced to an imprisonment of more than 7 years, or to an imprisonment up to a lifetime.

Article 87: Soldiers, who plunders clothes and properties from the dead, or the wounded, or the sick on the battlefield, will be sentenced to an imprisonment of more than a year.

Article 88: If a soldier, who has committed the previous two crimes, hurts civilians, he will be sentenced to an imprisonment of more than 7 years, or to an imprisonment up to lifetime. If a soldier kills civilians, he will be sentenced to a lifetime imprisonment, or to the death penalty.

Article 88.2: The empire soldiers on the battlefield, who rape women on the occupied land, will be sentenced to an imprisonment of more than a year, or an imprisonment up to lifetime. If a soldier, who has committed the previous crime, hurts civilians, he will be sentenced to an imprisonment of more than 3 years, or to an imprisonment up to lifetime; If a soldier kills civilians, he will be sentenced to lifetime imprisonment, or to the death penalty or an imprisonment of more than 7 years.

Article 89: Attempts of the crimes under this chapter are punishable. ${ }^{9}$

Even if the law might not be clear, severe, and effective enough to prevent war crimes from happening, it was still the law that regulated Japanese soldiers' behaviour. However, due to lapses in military disciplines and the poor education and training of Japanese soldiers at the time, the war crime rate was not under control. In order to prevent mischievous and deteriorating behaviour from spreading, Hideki Tojo, the Minister of the Imperial Japanese Army at the time, gave lectures about, Senjinkun (1941) [15], the Japanese Military Field Code, to reaffirm the discipline of the Japanese army.

\section{Lecture One, First, Imperial Army}

Valour requires strictness, while benevolence must be universal. Should there be an enemy who dares to oppose the Imperial army, the army must resolutely resort to force of arms and deal him a crushing blow. However, even though

\footnotetext{
9 Author's translation. The original text:

第九章 掠奪及強姦ノ罪第八十六条 戦地又八帝国軍ノ占領地二於テ住民八財物习掠奪シ夕ル者八 一年以上ノ有期懲役二処ス2 前項ノ罪习犯ス二当'婦女 7 強姦シタルトキハ無期又八七年以上ノ懲役二 処第八十七条 戦場二於テ戦死者又八戦傷病者ノ衣服其八他ノ財物习裭奪シ夕ル者八一年以上ノ有 期懲役二処又第八十八条 前二条)罪习犯ス者人 7 傷シ夕ルトキ八無期又八七年以上ノ懲役二処洌二 致シタルトキ八死刑又八無期懲役二処又第八十八条人二 戦地又八帝国軍ノ占領地二於于婦女 引強姦シ タル者八無期又ハ一年以上ノ懲役二処ス 2 前項ノ罪 7 犯者人 7 傷シタルトキハ無期又八三年以上ノ懲 役二処シ死二致シタルトキ八死刑又八無期若八七年以上ノ懲役二処又第八十九条 本章ノ未逐罪八之习 罰ス [14]. Thanks to my dear colleague Mrs. Rieko Hattori, lecturer in Japanese at Dalarna University, helped correcting my English translation of the Japanese Army Criminal codes in Japanese.
} 
force may compel the enemy to submit, should a lapse in virtue occur by striking of those who do not resist or by failure to show kindness to those who surrender, it cannot be said that such an army is perfect.

Modesty in its strength, unostentatious in its kindness, the Imperial Army becomes the object of admiration when it quietly displays its valour and benevolence. The mission of the Imperial Army lies in making the Imperial virtues the objects of universal admiration through the exercise of justice tempered with mercy. [10] ${ }^{10}$

Lecture Three, First, Prohibitions on the battlefield...

6. Enemies' properties and materials should be protected carefully. All the expropriation, confiscation, and disposal should follow the rules and commander's orders.

7. Since the fact that loyalty and righteousness are the natures of the imperial army, innocent and reluctant civilians should be well protected with kindness and mercifulness.

8. In battles, the imperial army's discretion should never be affected by alcohol, or by the sexual act because it will damage the reverence for the imperial army and jeopardize their individual duty. The virtue of imperial warriors should never be contaminated. ${ }^{11}$

Tojo's Senjinkun lectures aimed to promote the idea that the Emperor is divine and merciful, and, to honour him, the imperial army should be merciful and kind to the prisoners and civilians of the occupied territory and should not commit crimes, such as plundering, raping, and killing without a justification or approval. Then the Chinese will respect the Japanese, love the Emperor and be docile under the control of the Empire of Japan. As Tojo's lectures suggest, Senjinkun is more like a regulation or guideline, which has been applied in the army, than a law that specifies the punishment. However, soldiers who violate this code of conduct will come under pressure from their peers and be scolded by superior officers and discipline committees.

The Senjinkun military field code was published more than 3 years after the Nanking Massacre had taken place. The absence of military provisions, Senjinkun,

\footnotetext{
${ }^{10}$ The original text: 軍は天皇統帥の下、神武の精神を体現し、以て皇国の威徳を顕揚し皇運の扶翼に 任ず。常に大御心を奉じ、正にして武、武にして仁、克く世界の大和を現ずるもの是神武の精神なり。武 は厳なるべし仁は遍きを要す。苟も皇軍に抗する敵あらば、烈々たる武威を振ひ断乎之を撃砕すべ。仮 令峻厳の威克く敵を屈服せしむとも、服するは撃たず従了は慈むの徳に欠くるあらば、未だ以て全しとは言 ひ難し。武は驕らず仁は飾らず、自ら溢るるを以て兽しとなす。皇軍の本領は恩威並び行はれ、遍く御綾 威を仰がしむるに在り。[15].

${ }^{11}$ Translated by the author, the original text:

本訓。その三。第一。戦陣の戒。六、敵産、敵資の保護に留意するを要す。徵発、押収、物資の 燼滅等は全て規定に従い、必ず指揮官の命に依るジし。七、皇軍の本義に鑑み、仁恕の心能〈無享の 住民を愛護すぎ。八、戦陣苟(いやしくも酒色に心奪われ、又は欲情に駆られて本心を失い、皇軍の 威信を損じ奉公の身を過るが如きことあるジからず。深く戒慎し、断して武人の清節を污さざらんことを期す ثl. [15].
} 
might help to explain their extreme conduct during the time of the Nanking Massacre both in reality and in the film. Many of the civilians in Nanking, as well as the Chinese caught up in other battle zones during this time, must have been deprived of their property, raped, and murdered. Of course, it is possible that uncontrolled and immoral Japanese soldiers were the cause of the Nanking Massacre. However, this would diminish the legal responsibility for such atrocities being attributed to high ranking officers, the Japanese government, and the Emperor, who were all put on trial at the International Military Tribunal for the Far East in 1946. In Black Sun IV, this debate about the responsibility of high ranking officers for the Nanking Massacre take place in a fabricated conversation between a few Japanese officers after the meeting held by General Matsui Iwane. One of the officers says:

Tani Hisao: He [General Matsui Iwane] doesn't know the meaning behind the Emperor's directives.... It [occupying China] can only be done by a special method... to stun and threaten them. Psychologically, we have to destroy the Chinese completely. We must make the Chinese fear and respect Japanese.... It's [using a special method] to rule China in the future. We have to take extreme measures. I suggest that we kill all people and burn all houses in Nanking. This way all the Chinese will remember the penalty for disobedience....

Nakajima Kesago: All the officers agree that this is the best way to carry out our Emperor's will... It's not a coincidence for General Asakanomiya Hatohikoo, ${ }^{12}$ the Emperor's uncle, to come to Nanking. Therefore, our Emperor's meaning is clear, isn't it? [12]

According to this conversation, the Emperor is understood to have implicitly endorsed the use of extreme measures to ensure the political advantage of the Japanese in their campaign against China. Their interpretation of the imperial rescript is postulated as being supported by the presence of the Emperor's uncle as the Emperor's representative. This narrative indicates that the Emperor, high ranking officers as well as soldiers, and low rank soldiers are all accomplices and guilty of the Nanking Massacre. Since a famous Japanese feudal lord Toyotomi Hideyoshi (1537-1598) articulated the intention to conquer China and colonize the whole Asia, ${ }^{13}$ mercilessly and cruelly intimidating Chinese people and suppressing any resistance was a rational method for the Japanese Empire.

\footnotetext{
12 Asakanomiya Hatohikoo, i.e. Prince Yasuhiko Asaka, was thought as the person who made an order to kill all people in Nanking. In the film he only shows up as the Emperor's representative.

13 In 1929, a document called the Tanaka Memorial was published in Shishi Yuebao 時事月報 in Nanking. A Chinese translation of a Japanese original, Tanaka Memorial is said to reveal the Japanese Empire's intention of conquering China. However, many scholars contend that it is a forgery.
} 


\section{Lucifer Effect}

Some people initiate hatred and justify their deeds using legal means, such as with the Nuremberg Laws ${ }^{14}$ that seemed to give German soldiers a direct instruction that it was legally permitted to humiliate or even kill Jewish people. In contrast, and how interesting it is, that in other contexts, the omission of certain words from a legal document, in this case the Imperial rescript, became a silent endorsement for massacre. Both approaches should be treated as a legalization process, meaning that every legal act, be it a positive action or a deliberate omission, leads to war for which perpetrators must held responsible. Soldiers and officers, who carried out war crimes like rape and murder, cannot be exonerated on the grounds that they were not instructed to obey international law. In addition, the Emperor, who did not specifically command Japanese soldiers to uphold international law, also cannot avoid accusations on the grounds that his failure to mention international law was not meant to incite soldiers' inhumane conduct.

Authority and ideology inform the law, the law mandates obedience and obedience numbs our conscience. Unconscious minds cease to question authority and ideology. Therefore, evil stems from authority and ideology and the laws that represent them, although there may be an evil part in all human nature. In 1971, Philip Zimbardo and his team conducted a famous, and also notorious, experiment called the Stanford prison experiment in which college students were divided into two groups, guards and prisoners, in order to examine their performances and the psychological transformations that took place based on their roleplay activity. The experiment was conducted in a prison-a punitive, restrictive and suppressive government institution. The experiment came to an abrupt end 6 days after it began, because of the many mishaps and conflicts that erupted between the guards, who were convinced that they represented authority and were supposed to execute the law, and the prisoners, who had been mistreated and wanted to stop the experiment. Although the circumstances surrounding the Stanford experiment are controversial, it reveals the psychological response that human beings are vulnerable and susceptible to authority and power. As Philip Zimbardo says:

Let's begin with a definition of evil. Mine is a simple, psychologically based one: Evil consists in intentionally behaving in ways that harm, abuse, demean, dehumanize, or destroy innocent others-or using one's authority and systemic power to encourage or permit others to do so on your behalf. In short, it is "knowing better but doing worse." [16]

Evil, then, is wrong things done by people who know they are wrong but still intentionally do them because authority and systemic power creates a scenario in which they are no longer individuals but are simply part of a larger group. ${ }^{15}$ This group

\footnotetext{
14 Passed in 1935, the Nuremberg laws contained racist and anti-semitic regulations concerning the German flag, citizenship in the German Reich and the 'Protection of German Blood and German Honour'.

15 As Milgram experiment (1961) shows that when someone's moral senses are taken out by the authority, and when someone is free from taking responsibility for his behaviours, around $65 \%$ of volunteers would shock the shock the victim with the highest level of 450 volts. Of course, the results of different Milgram's experiments are subject to different variation controls. [17].
} 
has the authority, or is authorized, and is legally justified to execute conduct that is normally considered malicious. Expressions like "I am just following the order that everyone else is following" and "I do not need to take responsibility for what I have done because the authority is the only one who is responsible" create the illusion that the individual is powerful and entitled to do whatever they wish to those who are defined as "others" since these others are not like us. A situation created by authority and the law, that makes individuals' behaviours deviate from social norms, disassociates individuals from their moral codes.

Mindlessly taking the first small step. Dehumanization of others. De-individuation of Self. Diffusion of personal responsibility. Blind obedience to authority. Uncritical conformity to group norms. Passive tolerance to evil through inaction or indifference. And it happens when you're in a new or unfamiliar situation. Your habitual response patterns don't work. Your personality and morality are disengaged. [18]

According to Philip Zimbardo's explanation, the reason why Japanese soldiers in Black Sun IV are capable of such atrocities is because they are in the unusual situation where their moral sense does not apply and where they believe that they have been empowered by the authority, in this case the Emperor and his non-elaborative rescript. The rescript in reality was made to give the Emperor an alibi for the mass-killing in Nanking. However, the rescript in the film, on the contrary, highlights the Emperor's legal responsibility for the Nanking Massacre. The dialogue between the Japanese officers mentioned above as a literary strategy is, on the one hand, designed to hold the Emperor, and the Japanese government, responsible for the Nanking Massacre, even though no clear orders were issued to the soldiers. One the other hand, since the Emperor did not specifically tell the soldiers not to follow international law, the soldiers and the officers are responsible for their own actions since they are rational and reasonable adults with sound minds. It is also the way the Emperor writes the rescript, which is intended to shift responsibility for the massacre to the officers and soldiers.

Philip Zimbardo's experiment, if applied to Black Sun IV, shows that good people-if the Japanese soldiers in the film are assumed to be good in everyday lifewill turn into evil if they are trapped in a unprecedently bad situation and empowered by an authority. However, this seems not to fully explain why Japanese soldiers can cross, effortlessly or not, their moral boundaries. Even though the Emperor's rescript can "instruct (the soldiers) without (saying the) instruction", liberate the soldiers' sense of guilt and free them from the fear of punishment, it is still difficult to explain how it is possible for Japanese soldiers to totally abandon their conscience and the moral codes they usually followed. Therefore, in the next sections, I will use the theory about dishonesty in psychology and behavioural economics, alongside 
the Emperor's rescript and the narratives in Black Sun $I V$, to demonstrate another interpretation of the Nanking Massacre.

\section{The Imperial Rescript}

Hirohito's rescript was a declaration of war on the United States and Great Britain announced in 1941, 3 years after the second Sino-Japanese war and the Nanking Massacre. While it was not written until 1941, it does explain why the Japanese Empire and the Republic of China had a military conflict. There is a paragraph in the rescript that explains it was not Japan, but the Chinese government in Chungking 重慶 led by Chiang Kai-shek 蔣介石 who was responsible for the second SinoJapan war.

More than 4 years have passed since China, failing to comprehend the true intentions of Our Empire, and recklessly courting trouble, disturbed the peace of East Asia and compelled Our Empire to take up arms. Although there has been re-established the National Government of China, with which Japan had effected neighbourly intercourse and cooperation, the regime which has survived in Chungking, relying upon American and British protection, still continues its fratricidal opposition. Eager for the realization of their inordinate ambition to dominate the Orient, both America and Britain, giving support to the Chungking regime, have aggravated the disturbances in East Asia. [19] ${ }^{16}$

The rescript blames the Chinese for causing the second Sino-Japanese War. According to it, the reason why Chiang started the war was because he misunderstood Japan's true intentions and thought that it wanted to conquer the whole of China. Even though the rescript views the war as Chiang's fault, obliging Japan to fight back, it continues to present the Japanese government and the Emperor as kind and generous refusing to hate China because of their long mutual history. Although Chiang and his government are "vermin" who have undermined the brotherhood between the two nations, Japan has been able maintain its familiar relationship with the rival National Government of China led by Wang Jingwei 汪精衛, who they believe to be the only legitimate authority in the country. Since Chiang and his government, along with the United States and Great Britain, were responsible for the second Sino-Japanese War and the Pacific War, Japan had good reasons to declare war on these enemies. They also can justify being cruel to the Chinese people who follow Chiang and his government's commands. As the propagandistic Japanese media slogan declared “vicious China should be punished" 暴支膺懲 bao zhi ying cheng.

\footnotetext{
16 中華民國政府暴二帝國ノ眞意 7 解セス濫二事 構へテ東亞ノ平和 7 覺亂シ遂二帝國ヨシテ干戈 7 執ル 二至ラシメ幻二四年有餘 經夘幸二國民政府更新スルア1帝國八之卜善隣)誼习結七相提攜スル二至しル

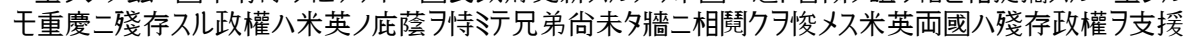
シテ東亞ノ禍亂 助長シ平和ノ美名ニ匿レテ東洋制覇ノ非望引逞ウセムトス.
} 
This document enables us to understand the attitude of the Emperor and the Japanese government towards their relationship with China and can be seen as an attempt to explain their actions between 1937 and 1941. The rescript was well written, not only completely removing Japan's responsibilities as the perpetrator of both wars, but also giving a perfect excuse for the cruelty it had inflicted on the Chinese people. It suggests that the Chinese in fact deserved to be treated inhumanely because it was China's fault for starting the war. In Black Sun IV the rescript is issued in 1937 thus providing an implicit order to the Japanese soldiers to carry out the atrocity in Nanking. In the film, the rescript provides a handy excuse to explain Japanese actions, to ease the soldiers' sense of guilt and give them a reason to carry out acts of cruelty on innocent Chinese people. Moreover, in the film the rescript acts like a psychological mechanism, turning off the Japanese soldiers' consciences, activating their self-deception, and justifying their sinister behaviour. In short, this rescript turns evil deeds into benign favours.

In the rescript, the "true intention" of the Japanese empire, from a psychological point of view, completely converts Japan's ambition, its military invasion of China, and the inhumane acts carried out by the Japanese soldiers at Nanking into favours that will help China transform from an old and weak country to a strong and modern country. What are their true intentions? General Commander Matsui Iwane, after publicly scolding Nakajima Kesago and Tani Hisao, two high-ranking Japanese officers, for events in Nanking, says:

Killing is just a method. In this holy war, you kill the Chinese in order to liberate them. This is absurd, but logical. Just like physical punishment for students. It's for their future. They must make sacrifices. In the long term, they will benefit from it. Sooner or later, the Chinese will appreciate the Japanese and the Japanese Emperor.... Each generation of Chinese is getting worse and worse. But the Japanese are growing stronger year by year. So we have to help the Chinese. Or Asia will be taken over by European and American powers. [12]

Killing the Chinese, becomes, in the words of Iwane in the film, a benign action for the Chinese people's own benefit. If the war could transform the Chinese people and government, China, an old country with a long history and many great traditions, could become a strong and modern country and take its rightful, yet subordinate place, as part of the Japanese-led Greater East Asia Co-Prosperity Sphere 大東亞共 榮圈. But how can mass killing and war crimes be seen as merciful methods to help China?

Pan-Asianism, [20] is the idea that Japan should help to make Asia strong and united so that it can fight against the Western world. In 1885, Fukuzawa Yukichi 福澤諭吉 (1835-1901) wrote an article in Jiji Shimpo 時事新報 titled “Leaving Asia Theory" (Datsu-A Ron 脫亞論) stating that China, along with Korea, is a terrible neighbour who will only drag Japan down and make it look as inferior to other Western countries as China really is. Japan did not need to treat countries like China and Korea well, for as Fukuzawa Yukichi says: 
Similar to the relations between our lips and teeth (that they exist in an inseparable relationship), neighbouring countries shall assist each other. Currently, China and Korea have not even offered a single drip of assistance to my Japan.... we (the Japanese people) do not have the luxury of time to wait for the enlightenment of our neighbouring countries - China and Korea-to work together toward the development of Asia. It is our best strategy to leave the ranks of Asian nations and cast our lot with the civilized nations of the West. As for our approach to the treating of China and Korea, there shall be no special treatment just because they are our neighbouring countries. Simply adapting the ways of the Westerners is sufficient. Those who cherish bad friends cannot escape the fate of being branded as a bad person. My heart and determination lie in the refusal of bad friends. [21] ${ }^{17}$

Yukichi's article affirms that only Japan knows how to improve, and that the Japanese are a superior species, both genetically and educationally, to the Chinese and the Korean. He says: "maybe it is due to the differences in racial origins (even though we share the same Asiatic teachings), there are differences in heredity and education," therefore, "no matter in an individual context or as a nation, the people of these two countries [China and Korea] do not know the way to progress". ${ }^{18}$ Since the Chinese are an inferior species, and not even human, the Japanese do not need to treat them equally. The Greater East Asia Co-Prosperity Sphere is a lie that Japan uses as manipulation. Japan uses it to sugar-coat and to justify everything inhumane they do to Chinese. Therefore, the Nanking Massacre is nothing vicious but is merely a benevolent wake-up call to Chinese.

\section{Dishonesty of Honest People}

As Matsui Iwane says in Black Sun IV, killing the Chinese is absurd but logical. But, how is it logical? We may find the answers in behavioural psychology theory. According to Dan Ariely, there are two types of dishonesty. One is the type of dishonesty that is conducted by people who know that what they are doing is dishonest while they are doing it, such as running a red light, stealing, and trespassing on other people's property. When about to break the law, these people will calculate the risks of being caught and the potential punishment, and weight them up against the benefits. If the result is worth the risk based on cost-benefit calculation, they will carry out the criminal conduct; otherwise, they will stop if the risk and the punishment

\footnotetext{
17 The original text: 輔車唇歯とは隣國相助くるの喻なれぞも、今の支那朝鮮は我日本のために一毫の 援助々爲らざるのみならず.... 我國は隣國の開明を待て共に亞細亞を興すの猶豫ある可らず、寧ろその伍 を脱して西洋の文明國と進退を共にい、其支那朝鮮に接するの法も隣國なるが故にとて特別の會釋に及ば ず、正に西洋人が之に接するの風に從て處分す可きのみ。惡友を親むむ者は共に惡友を免かる可らず。 我は心に於て亞細亞東方の惡友を謝絶するものなり。

18 The original text: 我日本國に異ならずと雖ども、其人種の由來を殊にするか、但しは同樣の政教風俗 中に居ながらも遺傳教育の旨に同じかざる所のものある歟... 此二國の者共は一身に就き又一國に關し てして改進の道を知らず。.
} 
are greater than they can handle. In short, law and punishment are external restraints that keep human instincts, desires, and impulses from deviating from social norms. The second type of dishonesty is conducted by people who think they are honest and do not know they are doing something dishonest [22, 196-197]. They either convince themselves that a dishonest thing they have done is honest or not that dishonest, or they sincerely believe that something dishonest they have done is actually honest. As Mazar, Amir and Ariely say:

We hypothesize that for certain types of actions and magnitudes of dishonesty, people can categorize their actions into more compatible terms and find rationalizations for their actions. As a consequence, people can cheat while avoiding any negative self-signals that might affect their self-concept and thus avoid negatively updating their self-concept altogether. [23, 634]

Everyone has a moral standard. Things within this limit are undoubtedly considered to be honest. For example, waiting at a red light in the middle of the night when there is no traffic. However, not everything is within the limit. Sometimes our moral standard will be challenged. When this happens, in order not to damage our perception of ourselves as "honest" we will stretch our standard and make it malleable. For example, the self-perception required to take some money from your friend's wallet to buy a pencil is completely different from the self-perception required to take a pencil from your friend's pencil box. Equally there are many possible explanations for the malleability of our moral standard when applied to the scenario "my friend took a pencil from me once; this is what friends do" [23, 634]. A moral code, moral standard, or self-perception is an internal examiner that checks if our behaviours are out of range. Ideally, our self-perception can regulate our behaviours every time since no one wants to be labelled as dishonest by others or by themselves. However, the same psychological mechanism also manipulates us to lie to ourselves because most people want to believe they are honest even they have done something dishonest. In other words, self-perception maintenance mechanism is meant to make us feel good about ourselves. Once our self-awareness of dishonesty gets lost and our selfperception maintenance mechanism takes control, it may induce self-deception, as Mazar and Ariely point out:

Other researchers have shown how people can be led to believe false or biased "facts" about their own past (see research on memory distortion and suppression of unwanted memories; e.g., Anderson [24]; Loftus 25; Schachter and Dodson [26]), and they can convince themselves of certain motivations for their behaviour, thus hiding their true intentions. Therefore, self-deception can be successful even in the most extreme cases: For example, doctors who participated in genocide in Nazi Germany managed to convince themselves of the rectitude of their actions [27]. [9, 28]

Memory is flexible and docile. We may change the facts in our memories to hide our true intentions or justify our behaviours to persuade ourselves and others that we are good people. Sometimes you know you are lying when you are lying, but, 
sometimes, you are not even aware you are lying if you truly believe that you are doing something benevolent. Dan Ariely talks about an experiment to test if people will lie about the number on dice they toss in order to win the money. In an interview about Elizabeth Holmes, the founder of Theranos, a company claiming it had created a machine that could test for every possible disease with a single drop of blood. Dan Ariely mentions that the polygraph can only detect your lies when you know you are lying. If, however, you sincerely believe that what you are saying is a truth, the lie detector cannot point you out.

In another version of the experiment, we do the same thing, but people pick a charity. And all the money that they're going to make today goes to that charity. Right? For a good cause. What do you think happened, people cheat more or less? People cheat more.

And the lie detector stops working. Why? Because what does the lie detector detect? The lie detector detects a tension. I want more money, but I think it's wrong. I want more money, but I think it's wrong, but if it's not wrong, why would you worry?

If it's for a good cause, you can still think of yourself as a good person, and that's how things start, and then it becomes a slippery slope. [29]

In Black Sun IV, Matsui Iwane truly believes that Pan-Asianism is the only approach: for the Empire of Japan to become the leader of Asia, and for China to become a modern country through a painful, Japanese-led transformation. Therefore, for the sake of helping China transform, Matsui Iwane will sanction all the necessary means even though they are evil. It is not that Matsui Iwane does not know the atrocities done by Japanese soldiers are evil. It is that he believes that if evil deeds are done for good purposes, they should no longer be considered evil. Judging if an action is evil or not is determined by the nature of the action and what the action can achieve. The only difference between Iwane and the officers Nakajima Kesago and Tani Hisao is that Iwane pretends to believe Japanese soldiers' behaviours are indecent. Kyogo and Hisao, however, never try to hide their true intention of fulfilling the Emperor's idea through killing. They are examples of why people who do dishonest/evil things can still think they are honest/good people.

\section{Opposition Against Justification}

Black Sun-The Nanking Massacre shows us how Japanese soldiers justify their killing based on the idea that, if the evildoings are for good purposes, they are not evil anymore. However, logical this may be, it is still absurd. Human beings are the only species that has a moral sense among all the living creatures on the planet. Something cruel can be done by nature, or by God, or by wild animals, without attracting moral criticism, but cannot be done by human beings, such as natural culling. Like the idea of an 'act of God', insurance companies will not pay for the damage caused by natural disasters. Compensations will only be made for the damage 
caused by actions or accidents which can be predicted and prevented by human minds. If someone or some country executes a culling process, the individual or country will be sentenced by law as guilty of mass killing even though it might be for a good cause. Therefore, the Nanking Massacre and the Holocaust ought never to have happened no matter what the reason was. "A good cause must be realized by a good means" is a moral principle that we, as moral beings, are educated to follow. It is also a legal principle on which all of the above-mentioned international laws are based. Morals and laws are consistent on the point that they cannot be overruled by any unratified international agreement, even by a rescript from the divine Emperor.

In Black Sun IV there is a conversation between a fictitious swordsman, the samurai Takayama and the army officer Nakajima Kesago. They debate about what methods should be used to defeat China and the Chinese people even though they both agree that this so-called holy war, the second Sino-Japanese war, is necessary. Nakajima thinks that Japan's military force is like a sword held by Futomyō (Aryaacalanatha, अचलनाथ in Sanskrit), able to destroy every obstacle on its way to the glory of the Japanese Empire, the success of the Greater East Asia Co-Prosperity Sphere, and the ideal of reforming the world and saving humanity. On the contrary, Takayama thinks that military force is only one way to win the war and it is not the way to win people's hearts and convince them that Japan is trying to free the whole of Asia from the control of the Western world. If a sword is only used to destroy, it will become evil, even though swords are made to protect oneself against evil and to fight against it. Takayama uses a story of swords as an analogy to persuade Nakajima to stop killing. Even though he fails, his story still acts as a strong opposition against the justification of mass killing and other inhumane behaviours.

Nakajima Kesago: But for sharpness, Masamune's swords are no match for those of his student, Mura Masa.

Takayama: But Masamune's sword is an expression of his character. It has a stunning power to one's soul. It is said that to compare swords for sharpness, put Mura Masa's sword in the middle of a river, and check the fate of dry leaves floating down. The leaves passing through the sword were all cut into halves. Then they put Masamune's sword to the same test, but most astonishing is the dry leaves automatically avoided his sword. Masamune had no interest in killing people. Because his perspective is that a sword should no longer be a killing tool. So Mura Masa's sword has not yet gone beyond the mere killing powers of a sword.... Mura Masa's sword represents the threatening power of a dictator. But because Masamune's sword is humanistic, it's superior. [12]

Military force, then, is not made to kill but to stop killing, as the Chinese character of military force $w u$ 武 suggests. The true meaning of $w u$ is to stop (zhi 止) using weapons ( $g e$ 戈). Moreover, the most powerful force is not military force, like Mura Masa's sword, that can defeat the enemy. The most powerful force is the power of culture, which is represented by the Masamune's sword, that can defeat enemies without fighting a war. Besides, building a military force is like sword forging, a process of self-cultivation. The purpose is to suppress the killing desire that arises 
from the instinct of self-protection. Since these ideas about military force exist in both Japanese and Chinese culture, the Japanese ought not to have used mass killing as a method to make the Chinese understand Japan's true intentions. Mass killing will make the Chinese remember only the massacre; the true intention will never be revealed. If one of the purposes of military force is to make the Chinese accept Japanese culture, love the Japanese emperor, and willingly follow the lead of the Japanese empire, a massacre ought never to have been allowed. It is impossible for the Chinese to embrace the beauty of Japanese culture when they are only fed with the evil part of it.

Black Sun-The Nanking Massacre not only shows us the cruelty of Japanese soldiers through its violent and graphic scenes. It also tells its audience that a good purpose must be achieved by proper and decent means. Although many war criminals from the second Sino-Japanese and the Pacific wars have been punished by law, not all of them realize that what they have done is not only legally wrong but is also evil in a moral sense. The conversation between Takayama and Nakajima in the film, therefore, is designed to refute the justification of a mass killing, and to tell Japanese soldiers, who have done evil things but still believe they are good, that they are actually deceiving themselves. Only when they realize the fact that they are immoral, can they really begin to repent their sins.

Funding Open access funding provided by Dalarna University.

Open Access This article is licensed under a Creative Commons Attribution 4.0 International License, which permits use, sharing, adaptation, distribution and reproduction in any medium or format, as long as you give appropriate credit to the original author(s) and the source, provide a link to the Creative Commons licence, and indicate if changes were made. The images or other third party material in this article are included in the article's Creative Commons licence, unless indicated otherwise in a credit line to the material. If material is not included in the article's Creative Commons licence and your intended use is not permitted by statutory regulation or exceeds the permitted use, you will need to obtain permission directly from the copyright holder. To view a copy of this licence, visit http://creativecommons.org/licen ses/by/4.0/.

\section{References}

1. United Nations Educational, Scientific and Cultural Organization. 2015. Memory of the WorldDocuments of Nanking Massacre. Retrieved from http://www.unesco.org/new/en/communicationand-information/memory-of-the-world/register/full-list-of-registered-heritage/registered-heritagepage-2/documents-of-nanjing-massacre/. Assessed 11 Sept 2020.

2. Drea, J. Edward et al. 2006. Researching Japanese War Crimes Records-Introductory Essays. Washington, DC: Nazi War Crimes and Japanese Imperial Government Records Interagency Group. Retrieved from https://www.archives.gov/files/iwg/japanese-war-crimes/introductory-essays.pdf. Assessed 7 Sept 2020.

3. BBC News. 4 February 2014. Governor of Japan broadcaster NHK denies Nanjing massacre. Retrieved from https://www.bbc.com/news/world-asia-26029614. Assessed 11 Sept 2020.

4. Tanaka, Masaaki. 2000. What really happened in nanking the refutation of a common myth. Sekai Shuppan: Sekai Shuppan trans.

5. American Experience. Humane treatment of prisoners of war (POWs). The 1907 Hague Convention which established the legal framework for the 'See. https://www.pbs.org/wgbh/americanexperience/ features/bataan-japan-pows-and-geneva-conventions/. Accessed 16 April 2020. 
6. Lillian Goldman Law Library. Kellogg-Briand Pact (1928). Yale Law School. Retrieved from https ://avalon.law.yale.edu/20th_century/kbpact.asp. Accessed 16 April 2020.

7. Durand, André, and Pierre Boissier. 1984. From Sarajevo to Hiroshima: History of the international committee of the red cross. Histoire du Comité international de la Croix-Rouge. Geneva: Henry Dunant Institute.

8. Hague, II. Laws and customs of war on land. Retrieved from https://www.loc.gov/law/help/us-treat ies/bevans/m-ust000001-0247.pdf. Assessed 16 April 2020.

9. Hague, IV. Laws and customs of war on land. Retrieved from https://www.loc.gov/law/help/us-treat ies/bevans/m-ust000001-0631.pdf. Assessed 16 April 2020.

10. Duhaime's Timetable of World Legal History. The Japanese military field code. http://www.duhai me.org/LawMuseum/LawArticle-1625/1941-The-Japanese-Military-Field-Code.aspx.

11. Godwin, George S. 1942. “Japan's new order”, Thinkers Forum No 23, 3-32. London: Watts.

12. Mou Tun Fei. 1995. Black sun: The nanking massacre (黑太陽: 南京大屠殺). Japan Shock. Retrieved from https://www.youtube.com/watch? $=$ DmXrvcIRtAA\&t=2898s.

13. Oshietegensan. Sexual Violence of the Army. Retrieved from http://www.oshietegensan.com/warhistory/war-history_i/3094/. Assessed 17 April 2020.

14. Japanese Military Criminal Code. Retrieved from https://web.archive.org/web/20190103170534/ http://www.geocities.jp/nakanolib/hou/hm41-46.htm. Accessed 17 April 2020, author's translation.

15. Hideki Tojo. 1941. Senjinkun military code lectures. NHK war testimonies. An audio recording of Tojo's lecture can be found at https://www2.nhk.or.jp/archives/shogenarchives/sp/movie.cgi?das_ id=D0001400144_00000.

16. Zimbardo, Philip. 2007. The lucifer effect-understanding how good people turn evil. New York: Random House.

17. Milgram, Stanley. 1974. Obedience to authority: An experimental view. New York: HarperCollins.

18. Zimbardo, Philip. 2008. The psychology of evil. Ted Speech https://www.ted.com/talks/philip_ zimbardo_the_psychology_of_evil.

19. National Diet Library Digital Collections. Official Announcement: Japanese declaration of war on the United States and the British Empire. 1941. https://dl.ndl.go.jp/info:ndljp/pid/2960976/18 For the English translation, see https://en.wikipedia.org/wiki/Japanese_declaration_of_war_on_the_ United_States_and_the_British_Empire.

20. Pan-Asianism (xing ya lun 興亞論). For a brief English introduction, see https://www.encycloped ia.com/history/dictionaries-thesauruses-pictures-and-press-releases/pan-asianism. For Chinese introduction, see The Chinese Encyclopaedia 華人百科 Hua Ren Bai Ke https://www.itsfun.com. tw/興亞論/wiki-0158901-5958301.

21. Kwok, Dwight, Tat Wai. 2009. A Translation of Datsu-A RON: Decoding a Prewar Japanese Nationalistic Theory. Graduate Department of East Asian Studies. University of Toronto. The translation into English is taken from https://tspace.library.utoronto.ca/bitstream/1807/18797/1/Kwok_ Dwight_TW_200911_MA_thesis.pdf.

22. Ariely, Dan. 2008. Predictably irrational-the hidden forces that shape our decisions. New York: HarperCollins Publishers.

23. Mazar, Nina. Amir, On. and Ariely, Dan. 2008. "The Dishonesty of Honest People: A Theory of Self-Concept Maintenance,” Journal of Marketing Research Vol. XLV (December 2008), 633-644.

24. Anderson et al. 2000: Anderson, Stephen J., Gillian Cohen, and Stephanie Taylor (2000), "Rewriting the Past: Some Factors Affecting the Variability of Personal Memories,' Applied Cognitive Psychology, 14 (5), 435-54.

25. Loftus, Elizabeth F. 1994. The Repressed Memory Controversy. American Psychologist 49 (5): 443-45.

26. Schachter, Stanley, and Chad S. Dodson. 2002. Misattribution, False Recognition and the Sins of Memory. In Episodic Memory: New Directions in Research, ed. Alan Baddeley, Martin Conway, and John Aggleton, 71-85. London: Oxford University Press.

27. Lifton, Robert J. 1986. Reflections on Genocide. Psychohistory Review 14 (3): 39-54.

28. Mazar, Nina, and Dan Ariely. 2006. "Dishonesty in everyday life and its policy implications. Journal of Public Policy \& Marketing 25 (1): 1-21.

29. Gibney, Alex. 2019. HBO documentary. The inventor: Out for blood in silicon valley.

Publisher's Note Springer Nature remains neutral with regard to jurisdictional claims in published maps and institutional affiliations. 